\title{
The Qur'ān as Literature: Literary Interpretation of the Qur'ān
}

\author{
Yusuf Rahman ${ }^{1}$
}

\begin{abstract}
This article argues that the Qur'ān is, among other thing, a literature, and therefore can be approached with literary interpretation. In order to support this idea, the article starts with demonstrating the literariness of the Qur'ān; showing the characteristics of literary interpretation of the Qur'ān; and ends with discussing the debates on literary interpretation of the Qur'an. The approach used in this article is literary to argue for the literariness and literary interpretation of the Qur'ān.
\end{abstract}

Keyword: literariness, al-tafsìi al-adabi, i 'jāz al-Qur’ān

\section{Introduction}

Before attempting to discuss the theory behind the literary approach to the Qur'ān, it would be useful to determine first whether in fact the Qur'ān may be regarded as literature. Even more to the point is the question: What is the "literariness" of the Qur'ān? Muslim scholars have in the past tried to demonstrate the literary qualities of the Qur'an by appealing to the concept of $i^{\prime}{ }^{\prime} j a \bar{z}$ al-Qur'ān (the miraculous nature of the Qur'ān), but, as Mustansir Mir has argued in his "The Qur'an as Literature," most of these writings are works of theology - wherein the superiority of the Qur'ān is asserted over other sacred or secular works -- rather than of literary criticism. ${ }^{2}$ Mir proposes that any discussion of this issue should be based on the principles of literary criticism. ${ }^{3}$

${ }^{1}$ Dosen Fakultas U shuluddin dan Sekolah Pascasarjana UIN Syarif Hidayatullah Jakarta. A lamat: JI. Kertamukti N o. 5, Pisangan Barat Cirendeu Ciputat, 1541. Email: yrahman@hotmail.com.

2 M ir, "The Qur'an as Literature." Religion \& Literature 20, 1 (1988): 49. See also his "Irony in the Qur'an: A Study of the Story of Joseph," in Literary Structures of Religious M eaning in the Qur'aA, ed. Issa J. B oullata (Richmond, Surrey: Curzon Press, 2000), 173.

${ }^{3}$ A ndrew Rippin would add that these principles are not simply those of A rab literary theory, but rather those of modern-day comparative literature. Rippin believes that the A rabic literary theory developed to prove the excellence of the Qur' ap. See his "The Qur'an as Literature: Perils, Pitfalls and Prospects," British Society for Middle Eastern Studies Bulletin 10, 1 (1983): 39. 
In a lecture delivered in 1982 on "The Qur'an as Literature: Perils, Pitfalls and Prospects," Andrew Rippin also suggested that in order to approach the Qur'an as literature, the basic assumption that the Qur'an is the Word of God and is therefore "above" other works of literature has to be disregarded. “To take the Qur'ān as literature," Rippin states, “... is to take it on the same plane as all other literary productions." There are of course many obstacles to studying the Qur'ān in this way. Rippin observes for instance that some Muslims perceive any critical approach to the Qur'ān to be an attack from outside. $^{6}$ Not only do some Muslims receive the critical studies by nonMuslims with suspicion, but also studies by liberal Muslims are distrusted. In most cases, those liberals are even excommunicated.

These conservative Muslims assert that as the Word of God (kaläm Allāh), the Qur'ān should be approached using a "special" method that is "appropriate" to the text itself. This common assumption that believers hold of the Qur'an makes it difficult to apply principles of literary theory to its analysis. Rudi Paret summarizes this view:

Since Muslims believe the Qur'ān to have been verbally inspired by God and to have always existed in Heaven in its original, ideal form $\ldots$, the Qur'an is not really a literary work at all, and cannot therefore be an object of study by literary historians. ${ }^{7}$

For literary scholars, however, the Qur'ān - like the Bible ${ }^{8}$-- is, as literature, liable to any approach. It does not require a special method of analysis simply because it is a divine text. Indeed, many of these literary critics are non-Muslims who would like to study the literary qualities of the Qur'an. But there are also Muslim scholars with an interest in literary theory. Consequently, they do not worry about whether such critical approaches, which are products of modern Western civilization, will distort the Qur'ān. Many Muslims, on the other hand, do worry that these "foreign" and "non-Islamic" approaches will lead to misinterpretation of the Qur'ān.

${ }^{4}$ The lecture is delivered in the Faculty of Humanities, University of Calgary and published in 1983. See n. 2 supra.

${ }^{5}$ Rippin "The Qur'an as Literature," 40.

${ }^{6}$ Rippin "The Qur'an as Literature," 41.

7 Paret, "The Qur'ān - I," in The Cambridge History of Arabic Literature: Arabic Literature to the End of the Umayyad Period, eds. A.F.L. Beeston, T.M. Johnstone, R.B. Serjeant and G.R. Smith (Cambridge: Cambridge University Press, 1983), 216.

${ }^{8}$ Leland Ryken and Tremper Longman III have argued the case with the Bible in their A Complete Literary Guide to the Bible (Grand Rapids, Michigan: Zondervan Publishing House, 1993), especially in "Introduction," 23-29. 
Some of the Qur'anic scholars even believe that the meaning of the Qur'an should be that which was understood by Muhammad and his contemporaries. These meanings, they claim, can be discovered through historical analysis of the works of previous tafsirs and the Prophet's sira. This position ignores the contention of literary scholars that the meaning of the text may lie in the author, the text, the context, or the reader, that the task of hermeneutics is not only to discover but also to create the meaning of the text. Given the many possibilities of locating the meaning of the text, the methods and approaches used to ascertain the analysis are consequently diverse.

In approaching the Qur'ān as literature, this article will examine the extent to which it exhibits a quality known as "literariness." But in order to do so, it will be necessary first of all to determine what constitutes literariness, i.e., what makes a work literature and what sets it apart from other non-literary works.

\section{What is Literature?}

What is literature? Literary theorists themselves find it difficult to define literature. Jonathan Culler, for example, argues in his Literary Theory: A Very Short Introduction, that nowadays the distinction between literary and non-literary works does not seem crucial. Both can be studied in similar ways. In addition, critics find that literariness, which is thought to be the chief quality of literary works, is to be found in non-literary works too. ${ }^{9}$ Terry Eagleton goes even further, saying that a piece of writing can be or ceases to be literature depending on the particular ideology which promote it. "[L]iterature," Eagleton states, "cannot in fact be 'objectively' defined. It leaves the definition of literature up to how somebody decides to read, not to the nature of what is written."10

Aside from these arguments, other theorists have suggested definitions of literature that may be of use for our discussion. The debate among these scholars revolves around whether literariness lies in the text ontologically or functionally. The Russian Formalists, who argue for the former, have long suggested that the literariness of literature lies in its use of peculiar language which differs from ordinary language. This feature, which is usually referred to

${ }^{9}$ Culler, Literary Theory: A Very Short Introduction (Oxford: Oxford University Press, 1997), 18.

10 Eagleton, Literary Theory: An Introduction (Minneapolis: University of Minnesota Press, 1983), 8. 
as the "foregrounding" of language, ${ }^{11}$ makes literature strange and unfamiliar to the reader. The "estranging" or "defamiliarizing" element in the text then leads to a particular degree of attention from the reader. In the words of Rene Wellek and Austin Warren, the authors of the classical handbook of literary method and theory, Theory of Literature, "[p]oetic language organizes, tightens, the resources of everyday language, and sometimes does even violence to them, in an effort to force us into awareness and attention."12

Eagleton disagrees with this definition, arguing that the deviation from ordinary language and the resulting sense of estrangement do not "always and everywhere" make a text literature. ${ }^{13}$ He takes as his example slang, which deviates from ordinary language but which cannot be considered as literature. Literariness, according to him, is a function that we apply to a text in considering it as literature.

While these particular theories are rather far apart in their views, they can be combined to yield a more comprehensive perspective on literature. David S. Miall and Don Kuiken have done just that in their recent article "What is Literariness? Three Components of Literary Reading."14 Based on empirical study of students' responses to a particular poem, they argue that literariness consists in three components of response to a literary text: first, the presence of stylistic variations in the text; second, the occurrence of defamiliarization in the mind of the reader; and finally, the process of interpretation following defamiliarization. These three components, Miall and Kuiken further suggest, have to be present and must interact with each other. It is on the basis of this definition that I will attempt in the following to discuss the literariness of the Qur'ān.

\section{The Literariness of the Qur'ān}

The basic property of a literary text is its foregrounding of language, which the Qur'ān does possess in abundance - so much so that readers and hearers tend to believe that it is poetry. Although the question of whether the Qur'ān contains poetry or $s a j$ '(rhymed prose) is a problem that has not yet been

${ }^{11}$ Culler, Literary Theory, 28. On the discussion of Russian Formalism, see ibid., 123-124; Eagleton, Literary Theory, 2-6.

${ }_{12}$ Rene Wellek and Austin Warren, Theory of Literature, Third Edition (New York: Harcourt, Brace \& World, Inc., 1956), 24.

${ }^{13}$ Eagleton, Literary Theory, 5.

${ }^{14}$ David S. Miall and Don Kuiken, "What is Literariness? Three Components of Literary Reading,” Discourse Process 28, 2 (1999): $122 \mathrm{ff}$. 
settled, there are in fact quite a number of verses which are rhythmic and rhyming. J.J. Gluck and Devin J. Stewart, for example, have demonstrated respectively the existence of poetry and $s a j$ ' in the Qur'ān. ${ }^{15}$ Besides these elements, the Qur'ān contains figures of speech, employs a variety of narrative techniques, and makes excellent use of words and phrases.

Whether reading or hearing these stylistic features in the Qur'ān, one is immediately struck by them. Sayyid Qutb (d. 1966) calls this "estranging" process sihr al-Qur'ān (the spell of the Qur'ān). ${ }^{16}$ This process of defamiliarization has been documented in the Qur'ān and the Sïra of Muhammad. Because of the beautiful language of the Qur'ān, many of Muhammad's contemporaries called him kāhin (diviner), shā'ir (poet) or majnūn (one who is possessed by jinn), accusations which the Qur'an categorically denies. Q. 69:40-43 for example states innahū la-qawlu rasūlin karìm. wa mā huwa bi-qawli shā'irin qaīila 'm-mā tu'minūn. wa là bi-qawli kähinin qaİila 'm-mā tadhakkarūn. tanzīlu 'm-mi 'r-rabbi 'l- 'ālamīn "That it is indeed the speech of the noble messenger. It is not poet's speech - little is it that you believe. Nor diviner's speech - little is it that you remember. It is a revelation from the Lord of the Universe."

In the Sira as well we come across stories about the reactions of Muhammad's opponents upon hearing the Qur'ān. It was upon hearing the verses of the Qur'ān for example that 'Umar b. al-Khattāa (d. 644) entered Islam, ${ }^{17}$ while al-Walid b. al-Mughïra, though he turned away from Islam, acknowledged the beauty of the Qur'ān. Nevertheless he had to convince his peers among Muhammad's enemies that the Qur'ān is nothing but the magic from of old (in hädhä illä sihrun yu'thar). ${ }^{18}$ This last incident is reflected in the Qur'ānic verse (Q. 74:21-24) thumma nazar, thumma 'abasa wa basar, thumma adbara wa 'stakbar, fa-qāla in hādhà illā siḥrun yu'thar "then he looked, then he

${ }^{15}$ See Stewart, "Saj' in the Qur'ān: Prosody and Structure," Journal of Arabic Literature 21, 2 (1990): 101-139, and Gluck, “Is There Poetry in the Qur'an?” Semitics 8 (1982): 43-89.

16 Sayyid Qutb, al-Tașiri al-Fannī fì al-Qur'ān (Many editions. The first was published in 1945 by Dār al-Ma'ärif, Cairo. Unless noted otherwise, this study uses the $14^{\text {th }}$ edition published by Dār al-Shurūq, Cairo in 1993), $11 \mathrm{ff}$.

${ }^{17}$ Quṭb, al-Tașwïr al-Fannī, 11-13, 25. See also Ibn Hishām, al-Sïra al-Nabawiyya,

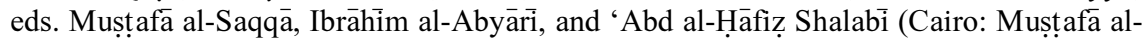
Bābì al-Ḥalabì, 1955), 342-346. For further discussion, see Issa J. Boullata, "Sayyid Quṭ's Literary Appreciation of the Qur'ān," in Literary Structure of Religious Meaning in the Qur'an, 357. 270-271.

${ }^{18}$ Quṭ, al-Tașwir al-Fannī, 13-14, 25. See also Ibn Hishām, al-Sïra al-Nabawiyya, 
frowned and showed displeasure, then he turned back and displayed arrogance. He said: This is nothing but magic from of old."

These two stories demonstrate that foregrounding of language evokes the feelings of those who understand the Arabic language regardless of their beliefs. Consequently, for our purposes Muslims and non-Muslims can appreciate equally the literary beauty of the Qur'ān. And it is for this reason that Mir suggests that, by considering the Qur'ān as literature, Muslim and non-Muslim scholars can work together to study from the perspective of literary criticism the literary aspect of the Qur'an, a discipline which is still in its infancy. ${ }^{19}$

The third component of literariness consists in reader's (or hearer's) response and interpretation of the literary text as the result of being defamiliarized and estranged with this foregrounding of language. While the relation between foregrounding and defamiliarization is quite clear, the third component, according to Miall and Kuiken, depends on the individual's response to the literary text. ${ }^{20}$ In the case of Qur'anic studies, some scholars are interested in the aesthetic aspect of the Qur'ān, some in the rhetorical way of how the verse is structured to achieve its effect, some in the aural sound and other elements of literary structures.

\section{Literary Interpretation (al-Tafsīr al-Adabī) of the Qur'ān}

Based on the above discussion of the literariness of the Qur'an, in this section I will discuss the literary interpretation of the Qur'ān. But again what do we mean by literary interpretation. There are writings which claim to be using a literary approach but do not provide a definition of what they mean by a literary approach. ${ }^{21}$ Others do not integrate Qur'ānic studies and literary criticism in their discussion. The pioneering work in that direction is Literary Structures of Religious Meaning in the Qur'an (henceforth cited as LSRMQ) edited by Issa J. Boullata, which invites literary scholars and Qur'ānic scholars to analyze and appreciate the Qur'ān from a literary point of view. ${ }^{22}$ But as is the case with many edited books, which gather a collection of articles, despite the editor's suggestion to the invited contributors to use recent literary theories

${ }^{19} \mathrm{Mir}$, "The Qur' an as Literature," 63.

${ }^{20}$ Miall and Kuiken, "What is Literariness?" 134.

${ }^{21}$ This similar objection has been advanced by Ryken and Longman III in the case of literary commentary on the Bible in their book Complete Literary Guide to the Bible, 9-10.

${ }^{22}$ See Boullata, "Introduction," in $L S R M Q$, xi. 
in their analysis of the Qur'ān, some of the articles do not represent that plan. In addition, since the book is similar to The Literary Guide to the Bible edited by Robert Alter and Frank Kermode, ${ }^{23}$ it is also victim to the same shortcoming -- indicated by the editors of A Complete Literary Guide to the Bible - "the volume offers no discernible or systematic literary method." 24 These weaknesses are not to belittle the many contributions of $L S R M Q$ but to encourage further studies on the topic.

\section{Characteristics of the Literary Interpretation of the Qur'ān}

One important feature of all literary approaches is the study of a text in its present form. In discussing the Qur'ān as literature, Mir, for example, argues in favor of "taking the Qur'an in its finished form as a starting point for literary investigation." 25 Does this means that one need not bother with - as Stefan Wild calls it -- "the pre-history of the Qur'anic text"? ${ }^{26}$ Wild for his part argues that the questions of influences and the genesis of the Qur'an are not of primary purpose for this approach.

In the case of Biblical interpretation, Jasper also states that instead of focusing on the context within which the Bible was written and had been understood, literary approaches are interested in the present text and its relation with the reader. "By focusing upon text rather than context," argues Jasper, "these literary readings of the Bible claim to overcome the hermeneutical problem of the 'two horizons', that is, the gap between the ancient text and the modern reader." 27 The latter, by looking at the literary qualities of the text, will find its power and meaning for the present context.

There is, however, a debate in Biblical interpretation about whether this synchronic approach neglects historical questions or vice versa. Ryken and Longman III, for example, argue in their Complete Literary Guide to the Bible that one of the pitfalls of the literary approach to the Bible is its refusal to concern itself with the question of history. ${ }^{28}$ The "shift of paradigm" -- from historical to literary interpretation -- furthermore points to the agenda of the latter as being that of moving away from such historical concern. John Barton,

\footnotetext{
${ }^{23}$ Cambridge, MA: The Belknap Press of Harvard University Press, 1987.

${ }^{24}$ See Ryken and Longman, Complete Literary Guide to the Bible, 10.

${ }^{25}$ Mir, "The Qur' an as Literature," 53.

${ }^{26}$ Stefan Wild, "Preface," in The Qur'an as Text, ed. S. Wild (Leiden: Brill, 1996),

27 Jasper, "Literary Readings of the Bible," 27.

${ }^{28}$ Ryken and Longman III, Complete Literary Guide, 26
} viii. 
on the other hand, argues that even the historical-critical interpretation deals with literary issues of the text. ${ }^{29}$ In an attempt to bridge this divide, Anthony C. Thiselton suggests that it is more constructive for Biblical interpretation to blend both approaches "draw[ing] on the strength of each approach while avoiding its distinctive weaknesses." 30 Similarly, Paul R. Noble in his "Synchronic and Diachronic Approaches to Biblical Interpretation"31 argues that even though these approaches ask different questions of the text, they cannot ignore each other, because they are studying the same text. Noble further explains this mutual relation:

The text was produced in a particular historical-cultural situation, knowledge of which is therefore indispensable for a sensitive synchronic reading; and conversely, historical reconstructions of what lies behind a text are dependent upon an accurate literary appreciation of the text's final form. ${ }^{32}$

In the case of literary interpretation of the Qur'an, this debate does not seem to be pertinent, since the proponents of al-tafsir al-adabi propose that both approaches be used in Qur'ānic interpretation.

A significant feature of literary interpretation lies in its focus on how the text communicates, before even addressing what it says. ${ }^{33}$ Based on a linguistic model of oral language, literary theorists maintain that a text is a communication between addresser/s and addressee/s. ${ }^{34}$ Literary studies, therefore, seek to examine the form and technique underlying work or works in question. If we take the articles in $L S R M Q$ as an example, we find that interests range over a wide field, such as: the communication process in the Qur'an (A.

29 Barton, "Historical-Critical Approach," in The Cambridge Companion to Biblical Interpretation, 14.

30 Thiselton, "On Models and Methods: A Conversation with Robert Morgan," in The Bible in Three Dimensions: Essays in Celebration of Forty Years of Biblical Studies in the University of Sheffield, eds. David J. Clines, Stephen E. Fowl, Stanley E. Porter (Sheffield: Sheffield Academic Press, 1990), 341, 343.

31 Noble, "Synchronic and Diachronic Approaches to Biblical Interpretation," Journal of Literature \& Theology 7, 2 (1993): 130-148.

${ }^{32}$ Noble, "Synchronic and Diachronic Approaches," 132.

${ }^{33}$ See Ryken, "The Bible as Literature: A Brief History," in A Complete Literary Guide to the Bible, 66; idem, "Literary Criticism of the Bible: Some Fallacies," in Literary Interpretations of Biblical Narratives, eds. Kenneth R.R. Gros Louis, with James S. Ackerman and Thayer S. Warshaw (Nashville, Tennessee: Abingdon Press, 1974), 27-28.

${ }^{34}$ Cf. Peter Dixon and Marisa Bortolussi, "Text Is Not Communication: A Challenge to a Common Assumption,” Discourse Processes 31, 1 (2001): 1-25. 
Neuwirth and A. Johns), ${ }^{35}$ how the süras are constructed ("structural unity" in A.M. Zahniser's and "formulaic feature" in A.T Welch's articles); ${ }^{36}$ literary elements in the Qur'ān (“irony” in Mir's, "ellipsis” in Y. Rahman's, majāz in Kamal Abu-Deeb's contributions). ${ }^{37}$ As a literary text which has affected Muslims, some contributors look at how Muslim readers have responded to the literary beauty of the Qur'ān (N. Kermani, M. Ayoub and Boullata). ${ }^{38}$ And finally, since the Qur'ān was originally recited orally, Michael Sells and Soraya Hajjaji-Jarrah examine the Qur'anic voice, whose meaning has had a great impact on its listeners. ${ }^{39}$ These articles suggest that how the Qur'an is written is seen as an issue that takes precedence over what the Qur'ān says.

\section{Literary Interpretation of the Qur'ān: Perils and Pitfalls}

Literary interpretation has not attracted the attention of many Qur'ānic scholars, whether Muslim or non-Muslim. This may be because literary criticism - to borrow Mark Allan Powell's phrase ${ }^{40}$-- is still considered a "second language" by many of these scholars, who for the most part rely on philological and historical analysis. Before the appearance of LSRMQ, some non-Qur'anic scholars who had been trained in the field of history of religions attempted, out of a sense of "dissatisfaction with existing approaches" in the field to apply literary theory to the Qur'ann. ${ }^{41}$ But the number of such studies is

${ }^{35}$ Neuwirth, "Referentiality and Textuality in Sürat al-Hijr," 143-172; Johns, "Reflections on the Dynamics and Spirituality of Sürat al-Furqān,"188-227.

36 Zahniser, "Major Transitions and Thematic Borders in Two Long Sūras: alBaqara and al-Nisā,,"26-55; Welch, "Formulaic Features of the Punishment-Stories," 77-116.

${ }^{37}$ Mir, "Irony in the Qur'an," 173-187; Rahman, "Ellipsis in the Qur'ān: A Study of Ibn Qutayba's Ta'wīl Mushkil al-Qur'ān," 277-291; and Abu-Deeb, "Studies in the Majāz and Metaphorical Language of the Qur'ān: Abū 'Ubayda and al-Sharif al-Raḍi," 310-353.

${ }^{38}$ Kermani, "The Aesthetic Reception of the Qur'ann as Reflected in Early Muslim History," 255-276; Ayoub, "Literary Exegesis of the Qur'ān: The Case of al-Sharif alRadịi," 292-309; and Boullata, "Sayyid Quțb's Literary Appreciation of the Qur'an," 354-371.

${ }^{39}$ Sells, "A Literary Approach to the Hymnic Sūras of the Qur'ān: Spirit, Gender, and Aural Intertextuality," 3-25; Hajjaji-Jarrah, "The Enchantment of Reading: Sound, Meaning, and Expression in Sürat al- "Addiyāt," 228-251.

${ }^{40}$ Powell, The Bible and Modern Literary Criticism: A Critical Assessment and Annotated Bibliography (New York: Greenwood Press, 1992), 3.

${ }^{41}$ See, for example, Richard C. Martin, "Structural Analysis and the Qur'an: Newer Approaches to the Study of Islamic Texts," Journal of the American Academy of Religion, Thematic Issue 47, 4S (1979): 665-683; idem, "Understanding the Qur'an in Text and Context," History of Religions 21 (1982): 361-384; Mohammed Arkoun, 
still small compared to the corresponding work being done in Biblical interpretation.

The variety of literary theory, furthermore, makes the adaptation of this new approach to the study of the Qur'an more difficult. Romanticism, New Criticism, Formalism, Structuralism, Post-structuralism, Reader-response criticism and Deconstruction are just some of the literary critical approaches available to Islamicists, who seem nevertheless to be largely unaware of them. M.H. Abrams's classification of the four types of literary criticism fortunately assists us in understanding the different schools of literary theory. ${ }^{42}$ The first broad category of criticism, according to Abrams, is mimetic, which views a literary work as imitating the world and evaluating it in terms of the accuracy of its representation. The second and third categories of criticism are pragmatic and expressive types. Pragmatic theory is reader-centered criticism that evaluates a literary work in terms of its effects on its readers, while expressive theory is author-centered criticism which evaluates a work in terms of its expression of the views and thought of its writer. Abrams calls the fourth category of theories the objective types of criticism that view a work as a world in itself.

These four types of criticism represent four elements surrounding the work itself, i.e., the work, the universe, the writer, and the reader, which are illustrated by Abrams as follows: ${ }^{43}$

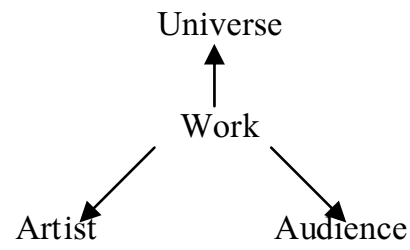

The history of literary criticism has recently seen a shift of focus from author-centered interpretation to reader-centered criticism. The latter argues that the role of the reader is not only to re-produce but also to produce the

Lectures du Coran (Paris: Maisonneuve and Larose, 1982); Marcia K. Hermansen, "Pattern and Meaning in the Qur'anic Adam Narratives," Studies in Religion/Sciences Religieuses 17, 1 (1988): 41-52; and other works mentioned in the latter article, especially p. $41 \mathrm{n} .1$.

42 Abrams, The Mirror and the Lamp: Romantic Theory and the Critical Tradition (New York: The Norton Library, 1958), 6-29.

${ }^{43}$ Abrams, The Mirror and the Lamp, 6. 
meaning of the text. David Jasper in his "Literary Readings of the Bible" nicely puts this theory as follows:

Reader-response criticism focuses on the reader as the creator of, or at the very least, an important contributor to, the meaning of texts. Rather than seeing 'meaning' as a property inherent in texts, whether put there by an author or somehow existing intrinsically in the shape, structure and wording of the texts, reader-response criticism regards meaning as coming into being at the meeting point of text and reader -- or in a more extreme form, as being created by readers in the act of reading. ${ }^{44}$

Many Biblical scholars have applied this criticism to the Bible, ${ }^{45}$ and some argue that it is time for Qur'anic scholars to do the same. Rippin has actually proposed in his above-mentioned article that the future of Qur'anic studies lies in "situating the Qur'an at the focal point of a reader-response study," ${ }^{46}$ but this proposal has not attracted many Qur'anic scholars yet.

Perhaps, the major difficulty in applying literary theory ${ }^{47}$ is the resistance shown by Muslims to this approach. Many consider it to be secular in nature and, as such, insist that it cannot be applied to the divine text. It is true that the chief threat posed by literary theory is its challenge to the authority of the text.

44 Jasper, "Literary Readings of the Bible," in The Cambridge Companion to Biblical Interpretation, ed. John Barton (Cambridge: Cambridge University Press, 1998), 18-19. This quotation indicates that there are, at least, two types of reader-response theory: the conservative and the radical. See Kevin J. Vanhoozer, "The Reader in New Testament Interpretation," in Hearing the New Testament: Strategies for Interpretation, ed. Joel B. Green (Michigan: Wm. B. Eerdamans Publishing Co. 1995), 301-328, especially $307 \mathrm{ff}$.

${ }^{45}$ Besides Jasper and Vanhoozer, see, for example, Edgar V. McKnight, The Bible and the Reader: An Introduction to Literary Criticism (Philadelphia: Fortress Press, 1985); Anthony C. Thiselton, New Horizons in Hermeneutics: The Theory and Practice of Transforming Biblical Reading (Grand Rapids, Michigan: Zondervan Publishing House, 1992), especially Chapter XIII. Cf. Stanley E. Porter, "Why Hasn't Reader Response Criticism Caught on in New Testament Studies?" Journal of Literature \& Theology 4, 3 (1990): 278-292.

${ }^{46}$ Rippin, "The Qur'an as Literature," 46; idem, "Introduction" in Approaches to the History of the Interpretation of the Qur'an, ed. A. Rippin (Oxford: Clarendon Press, 1988), 3-4. See for instance Jane D. McAuliffe who reads Q. 3:7 in the light of readerresponse theory in her "Text and Textuality: Q. 3:7 as a Point of Intersection," LSRMQ, 56-76. Compare this with A. Neuwirth who, instead of using reader-response theory, analyzes the Qur'an in terms of communication process between speaker and listener (thus listener-response theory) in her, "Referentiality and Textuality in Sürat al-Hijr: Some Observations on the Qur'anic "Canonical Process" and the Emergence of a Community," LSRMQ, 143-172, especially, 145ff.

47 Some objections in applying literary criticism to the Bible, which are summarized by Powell, may also be appropriated to the Qur'an. See Powell, The Bible and Modern Literary Criticism, 16-17. 
The Qur'ān as the "sacred text" or the Word of God becomes subject, like all other literature, to any critical approach. Furthermore, different interpretive schools, whether feminist, Marxist, Liberation theology critics - or "oppositional discourses" as Wolfgang Iser calls them ${ }^{48}$ - will be tempted to attack the authority of the Qur'ān as has been done to the Bible. ${ }^{49}$ These oppositional critics challenge the ideology which, they believe, was implanted in the text by its author/s. ${ }^{50}$ Feminist readings, for instance, will dispute its "patriarchal" ideology, while materialist and Liberation theology critics will argue against the economic and political oppressions promoted by the text.

The argument of these different schools, furthermore, imply that the meaning of the text is indeterminate. It is the reader who creates the meaning and lends the text whatever sense it possesses, depending on his/her interest. If the interests of the readers are different, it is inevitable that the text will mean different things to different readers. Consequently, there is no one determinate meaning that the reader is bound to discover in the text. This position, according to Muslim critics, confuses believers who, instead of a variety of relative meanings, would like to have some concrete and objective thing to hold on to.

Reader-response theory, therefore, allows for a variety of readings. To the question, "Which of these readings is correct?", literary scholars would say that there are no universal objective criteria to validate a reading. This conviction stems from the perception that objective interpretation is an expression of power. "Those in power," writes Terence J. Keegan in his "Biblical Criticism and the Challenge of Postmodernism," "whether political, economic, scholarly or religious, tend to justify their power by appealing to objective analyses that support the structured world they dominate." ${ }^{51}$ In the case of interpretation, therefore, the authority that sanctions a certain meaning

${ }^{48}$ Wolfgang Iser, The Range of Interpretation (New York: Columbia University Press, 2000), 4.

${ }^{49}$ In the case of Biblical interpretation see, for example, Jasper, "Literary Readings of the Bible," 28ff.; idem, "Literary Readings of the Bible: Trends in Modern Criticism," in The Bible and Literature: A Reader, eds. David Jasper and Stephen Prickett (Oxford: Blackwell Publishers, 1999), 57ff.; and Terence J. Keegan, "Biblical Criticism and the Challenge of Postmodernism," Biblical Interpretation 3, 1 (1995): 114.

${ }^{50} \mathrm{Cf}$. Stephen Fowl, who challenges the claim that texts have ideologies, in his “Texts Don't Have Ideologies," Biblical Interpretation 3, 1 (1995): 15-34.

${ }^{51}$ Keegan, "Biblical Criticism and the Challenge of Postmodernism," 1. 
and outlaws others lies in what Stanley Fish calls "interpretive communities,"52 that is, a group of individuals who share similar interpretive strategies in reading. These interpretive strategies, however, apply only to certain interpretive communities and cannot be imposed on others.

\section{Conclusion}

Despite the many objections leveled against the literary approach, however, it can still be seen to offer many benefits for Qur'anic interpretation. It challenges, for instance, the absolutists, who claim to know the true meaning and the true interpretation of the text. ${ }^{53}$ In keeping with the concept of interpretive communities, it can at the same time help to refute the subjectivists who would have the texts mean only what fits their own interests. Werner G. Jeanrond in speaking about the crisis in Biblical interpretation, argues that hermeneutics (I would add, literary theory too) is not the cause of this crisis. He states:

Hermeneutics, the study of proper means of text-interpretation, is not the cause of the current crisis in biblical studies, rather it may point indirectly to some ways out of this crisis. Of course, it is true to say that hermeneutics has destroyed the claims to any total objectivity in biblical interpretation, theology and any other discipline of human knowledge. But hermeneutics has equally invalidated the pretensions of any purely subjectivist approach to biblical texts, i.e. approaches based on nothing other than the conviction that one's preferred theory of what the biblical text ought to say or stand for is just fine. Thus, it has become obvious that neither objectivist nor subjectivist ideologies of reading have helped the critical reader any further in her or his attempt to understand the potential of meaning in biblical texts, or indeed any other written or oral texts. ${ }^{54}$

${ }^{52}$ Stanley Fish, Is There a Text in This Class?: The Authority of Interpretive Communities (Cambridge, Mass.: Harvard University Press, 1980), 14, 16, 317; David J.A. Clines, "Possibilities and Priorities of Biblical Interpretation in an International Perspective," Biblical Interpretation 1, 1 (1993): 79; David J.A. Clines, and J. Cheryl Exum, "The New Literary Criticism," in The New Literary Criticism and the Hebrew Bible, eds. J. Cheryl Exum and David J.A. Clines (Sheffield: Sheffield Academic Press, 1993), 19. In Qur'anic studies, see McAuliffe, "Text and Textuality," 68-69.

${ }^{53}$ In his discussion of the marketplace of interpretation, Iser places this absolutist view as the first trend, i.e., "monopoly of interpretation." The second and third trends are "the conflict of interpretation," and "oppositional discourses." See Iser, The Range of Interpretation, especially Chapter One.

54 Jeanrond, "After Hermeneutics: The Relationship between Theology and Biblical Studies," in The Open Text: New Directions for Biblical Studies? ed. Francis Watson (London: SCM Press Ltd., 1993), 85. 
Contemporary literary theory furthermore encourages readers continuously to search for new meanings of the text. Literary theory and other new approaches to the Qur'an can stimulate discussion of those areas that Mohammed Arkoun calls l'impensable and l'impensé. 55 They are "unthinkable" and "unthought of" only because of the limitations of the available methods, or because of the ideological constraints that prevent one from studying an issue critically.

Finally, with Mir, I argue that the Qur'ān is not exclusively a theological text; it is also literature. Even Sayyid Qutb once argued that three quarters (thalāthat arbā') of the Qur'ān consists of literature. ${ }^{56}$ Although one can raise the objection that the literary approach is limited in what it can do with the Qur'anic text, the same thing can be said of many other approaches.

\section{Bibliography}

Abrams, M.H. The Mirror and the Lamp: Romantic Theory and the Critical Tradition. New York: The Norton Library, 1958.

Abu-Deeb, Kamal. "Studies in the MajäZ and Metaphorical Language of the Qur'ān: Abū 'Ubayda and al-Sharif al-Raḍi." In Literary Structures of Religious Meaning in the Qur'ān. Ed. Issa J. Boullata. Richmond, Surrey: Curzon Press, 2000, 310-353.

Alter, Robert and Frank Kermode (Eds.). The Literary Guide to the Bible. Cambridge, MA: The Belknap Press of Harvard University Press, 1987.

Arkoun, Mohammed. Lectures du Coran. Paris: Maisonneuve and Larose, 1982.

Ayoub, Mahmoud. 'Literary Exegesis of the Qur'ān: The Case of al-Sharif alRadi.." In Literary Structures of Religious Meaning in the Qur'ān. Ed. Issa J. Boullata. Richmond, Surrey: Curzon Press, 2000, 292-309.

Barton, John. "Historical-Critical Approach." In The Cambridge Companion to Biblical Interpretation. Ed. John Barton. Cambridge: Cambridge University Press, 1998, 9-20.

Boullata, Issa J. "Sayyid Quṭb's Literary Appreciation of the Qur'ān." In

${ }^{55}$ See Arkoun, Lectures du Coran, xiiff. See also Issa J. Boullata, Trends and Issues in Contemporary Arab Thought (Albany: State University of New York Press, 1990), 81-82.

${ }^{56}$ Qutb's comment to the third edition of al-Taswir al-Fanni, which is reprinted in the $14^{\text {th }}$ edition, 254. See also idem, Mashāhid al-Qiyāma fì al-Qur'ān (Kairo: Dār alMa'ārif, 1953, 8. 
Literary Structures of Religious Meaning in the Qur'ān. Ed. Issa J. Boullata. Richmond, Surrey: Curzon Press, 2000, 354-371.

. Trends and Issues in Contemporary Arab Thought. Albany: State University of New York Press, 1990.

Clines, David J.A. "Possibilities and Priorities of Biblical Interpretation in an International Perspective," Biblical Interpretation 1, 1 (1993): 67-87.

and J. Cheryl Exum. "The New Literary Criticism." In The New Literary Criticism and the Hebrew Bible. Eds. J. Cheryl Exum and David J.A. Clines. Sheffield: Sheffield Academic Press, 1993, 11-25.

Culler, Jonathan. Literary Theory: A Very Short Introduction. Oxford: Oxford University Press, 1997.

Dixon, Peter and Marisa Bortolussi, “Text Is Not Communication: A Challenge to a Common Assumption.” Discourse Processes 31, 1 (2001): 1-25.

Eagleton, Jonathan. Literary Theory: An Introduction. Minneapolis: University of Minnesota Press, 1983.

Fish, Stanley. Is There a Text in This Class?: The Authority of Interpretive Communities. Cambridge, Mass.: Harvard University Press, 1980.

Fowl, Stephen. "Texts Don't Have Ideologies." Biblical Interpretation 3, 1 (1995): 15-34.

Gluck, J.J. “Is There Poetry in the Qur'ān?” Semitics 8 (1982): 43-89.

Hajjaji-Jarrah, "The Enchantment of Reading: Sound, Meaning, and Expression in Sürat al- 'Adiyät," In Literary Structures of Religious Meaning in the Qur'ān. Ed. Issa J. Boullata. Richmond, Surrey: Curzon Press, 2000, 228251.

Hermansen, Marcia K. "Pattern and Meaning in the Qur'anic Adam Narratives." Studies in Religion/Sciences Religieuses 17, 1 (1988): 41-52.

Ibn Hishām. al-Sīra al-Nabawiyya. Eds. Muṣtafāa al-Saqqā, Ibrāhīm al-Abyārī,

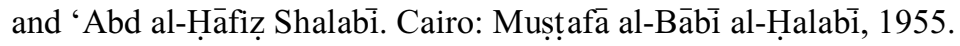

Iser, Wolfgang. The Range of Interpretation. New York: Columbia University Press, 2000.

Jasper, David. "Literary Readings of the Bible: Trends in Modern Criticism." In The Bible and Literature: A Reader. Eds. David Jasper and Stephen Prickett. Oxford: Blackwell Publishers, 1999, 44-64.

" "Literary Readings of the Bible." In The Cambridge Companion to Biblical Interpretation. Ed. John Barton. Cambridge: Cambridge University Press, 1998, 21-34.

Jeanrond, Warner G. “After Hermeneutics: The Relationship between Theology and Biblical Studies." In The Open Text: New Directions for Biblical Studies? Ed. Francis Watson. London: SCM Press Ltd., 1993, 85-102.

Johns, Anthony H. "Reflections on the Dynamics and Spirituality of Sürat alFurqān.” In Literary Structures of Religious Meaning in the Qur'ān. Ed. Issa J. Boullata. Richmond, Surrey: Curzon Press, 2000, 188-227. 
Keegan, Terence J. "Biblical Criticism and the Challenge of Postmodernism." Biblical Interpretation 3, 1 (1995): 1-14.

Kermani, Navid. “The Aesthetic Reception of the Qur'an as Reflected in Early Muslim History." In Literary Structures of Religious Meaning in the Qur'ān. Ed. Issa J. Boullata. Richmond, Surrey: Curzon Press, 2000, 255276.

Martin, Richard C. "Structural Analysis and the Qur'an: Newer Approaches to the Study of Islamic Texts." Journal of the American Academy of Religion, Thematic Issue 47, 4S (1979): 665-683.

-------. "Understanding the Qur'ān in Text and Context." History of Religions 21 (1982): 361-384.

McAuliffe, Jane D. “Text and Textuality: Q. 3:7 as a Point of Intersection." In Literary Structures of Religious Meaning in the Qur'ān. Ed. Issa J. Boullata. Richmond, Surrey: Curzon Press, 2000, 56-76.

McKnight, Edgar V. The Bible and the Reader: An Introduction to Literary Criticism. Philadelphia: Fortress Press, 1985.

Miall, David S. and Don Kuiken. "What is Literariness? Three Components of Literary Reading." Discourse Process 28, 2 (1999): 121-138.

Mir, Mustansir. “The Qur'an as Literature.” Religion \& Literature 20, 1 (1988): 49-64.

" "Irony in the Qur'ān: A Study of the Story of Joseph." In Literary Structures of Religious Meaning in the Qur'an. Ed. Issa J. Boullata. Richmond, Surrey: Curzon Press, 2000, 173-187.

Neuwirth, A. "Referentiality and Textuality in Sürat al-Hijr: Some Observations on the Qur'anic "Canonical Process" and the Emergence of a Community," In Literary Structures of Religious Meaning in the Qur'ān. Ed. Issa J. Boullata. Richmond, Surrey: Curzon Press, 2000, 143172

Noble, Paul. "Synchronic and Diachronic Approaches to Biblical Interpretation." Journal of Literature \& Theology 7, 2 (1993): 130-148.

Paret, Rudi. "The Qur'ān - I." In The Cambridge History of Arabic Literature: Arabic Literature to the End of the Umayyad Period. Eds. A.F.L. Beeston, T.M. Johnstone, R.B. Serjeant and G.R. Smith. Cambridge: Cambridge University Press, 1983.

Porter, Stanley E. "Why Hasn't Reader - Response Criticism Caught on in New Testament Studies?" Journal of Literature \& Theology 4, 3 (1990): 278292.

Powell, Mark Allen. The Bible and Modern Literary Criticism: A Critical Assessment and Annotated Bibliography. New York: Greenwood Press, 1992.

Quṭb, Sayyid. Mashāhid al-Qiyāma fī al-Qur'ān. Many editions. The first is published in Cairo in 1947; the second by Dār al-Ma‘ārif, in 1953; and the seventh in $1981 .$. 
al-Taswir al-Fannī fí al-Qur'ān. The first was published in 1945 by Dār al-Ma'ārif, Cairo. The $14^{\text {th }}$ edition published by Dār al-Shurūq, Cairo in 1993.

Rahman, Yusuf. "Ellipsis in the Qur'ān: A Study of Ibn Qutayba's Ta'wil Mushkil al-Qur'ann." In Literary Structures of Religious Meaning in the Qur'ān. Ed. Issa J. Boullata. Richmond, Surrey: Curzon Press, 2000, 277291.

Rippin, Andrew. "Introduction." In Approaches to the History of the Interpretation of the Qur'ān. Ed. A. Rippin. Oxford: Clarendon Press, 1988.

"The Qur'an as Literature: Perils, Pitfalls and Prospects." British Society for Middle Eastern Studies Bulletin 10, 1 (1983): 38-47.

Ryken, Leland. "The Bible as Literature: A Brief History." In Ryken, Leland and Tremper Longman III (Eds.). A Complete Literary Guide to the Bible. Grand Rapids, Michigan: Zondervan Publishing House, 1993, 4968 .

"Literary Criticism of the Bible: Some Fallacies." In Literary Interpretations of Biblical Narratives. Eds. Kenneth R.R. Gros Louis, with James S. Ackerman and Thayer S. Warshaw. Nashville, Tennessee: Abingdon Press, 1974, 27-28.

Sells, Michael. "A Literary Approach to the Hymnic Süras of the Qur'an: Spirit, Gender, and Aural Intertextuality." In Literary Structures of Religious Meaning in the Qur'ān. Ed. Issa J. Boullata. Richmond, Surrey: Curzon Press, 2000, 3-25.

Stewart, Devin J. "Saj' in the Qur'ān: Prosody and Structure." Journal of Arabic Literature 21, 2 (1990): 101-139.

Thiselton, Anthony C. New Horizons in Hermeneutics: The Theory and Practice of Transforming Biblical Reading. Grand Rapids, Michigan: Zondervan Publishing House, 1992.

" "On Models and Methods: A Conversation with Robert Morgan." In The Bible in Three Dimensions: Essays in Celebration of Forty Years of Biblical Studies in the University of Sheffield. Eds. David J. Clines, Stephen E. Fowl, Stanley E. Porter. Sheffield: Sheffield Academic Press, 1990.

Vanhoozer, Kevin J. "The Reader in New Testament Interpretation.” In Hearing the New Testament: Strategies for Interpretation. Ed. Joel B. Green. Michigan: Wm. B. Eerdamans Publishing Co. 1995, 301-328.

Welch, Alford T. "Formulaic Features of the Punishment-Stories." In Literary Structures of Religious Meaning in the Qur'an. Ed. Issa J. Boullata. Richmond, Surrey: Curzon Press, 2000, 77-116.

Wellek, Rene and Austin Warren. Theory of Literature. Third Edition. New York: Harcourt, Brace \& World, Inc., 1956.

Wild, Stefan (Ed.). The Qur'an as Text. Leiden: Brill, 1996. 
Zahniser, A.H. Mathias. "Major Transitions and Thematic Borders in Two Long Süras: al-Baqara and al-Nisā,", In Literary Structures of Religious Meaning in the Qur'ān. Ed. Issa J. Boullata. Richmond, Surrey: Curzon Press, 2000, 26-55. 